\title{
Floral and Pollen Traits of Moringa oleifera Lam. and Moringa peregrina (Forssk.) Fiori Provide Reproductive Adaptations for Arid Conditions
}

\author{
Yiftach Vaknin ${ }^{1, *}$, Dan Eisikowitch ${ }^{2}$ and Adina Mishal ${ }^{3}$ \\ 1 Department of Natural Resources, Institute of Plant Sciences, Agricultural Research Organization, \\ The Volcani Center, 68 HaMaccabim Road, P.O. Box 15159, Rishon LeZion 7505101, Israel \\ 2 Department of Plant Sciences, George S. Wise Faculty of Life Sciences, Tel Aviv University, \\ Tel Aviv 69978, Israel; dane@tauex.tau.ac.il \\ 3 Faculty of Science, Kibbutzim College of Education, Tel Aviv University, 149 Derech Namir, \\ Tel Aviv 6250769, Israel; adinamish@gmail.com \\ * Correspondence: yiftachv@volcani.agri.gov.il; Tel.: +972-3-968-3486
}

check for updates

Citation: Vaknin, Y.; Eisikowitch, D.; Mishal, A. Floral and Pollen Traits of Moringa oleifera Lam. and Moringa peregrina (Forssk.) Fiori Provide Reproductive Adaptations for Arid Conditions. Agronomy 2021, 11, 1090. https://doi.org/10.3390/ agronomy 11061090

Academic Editor: Yehoshua (Shuki) Saranga

Received: 11 May 2021

Accepted: 25 May 2021

Published: 27 May 2021

Publisher's Note: MDPI stays neutral with regard to jurisdictional claims in published maps and institutional affiliations.

Copyright: (c) 2021 by the authors. Licensee MDPI, Basel, Switzerland. This article is an open access article distributed under the terms and conditions of the Creative Commons Attribution (CC BY) license (https:// creativecommons.org/licenses/by/ $4.0 /)$.

\begin{abstract}
Our study attempted to elucidate the significance of floral and pollen traits of the highly nutritious tropical trees Moringa oleifera and Moringa peregrina for their reproductive success under arid conditions. We found that the pollen grains of both species were immersed in a pollenkitt that constituted $\sim 60 \%$ of the pollen. Successful pollination was achieved by large bees inserting the pollen into a narrow stylar tube. We found that, upon removal of the pollenkitt, approximately $65 \%$ fewer pollen grains penetrated the stylar tube for both species. The pollenkitt protected against heat and desiccation, while removing the pollenkitt resulted in significantly reduced levels of the viability of pollen grains, especially in M. oleifera, and significantly reduced levels of germinability in both species. The stylar tube provided high protection for pollen grains against heat and desiccation even when the pollenkitt was removed. Chemical analysis of pollenkitts of the two species revealed a waxy blend of 21 hydrocarbon compounds, in which $n$-alkanes constituted $>90 \%$ of the compounds and their identity corresponded to known plant and animal hydrocarbons, associated with protection against heat and water stress. We concluded that, under arid conditions, the reproductive success of both Moringa species is potentially enhanced by their unique floral and pollen traits. This supports the prospect of cultivating $M$. oleifera and Moringa peregrina as food crops in arid regions across the globe.
\end{abstract}

Keywords: arid conditions; pollen adhesion; pollen germinability; pollenkitt; pollen viability; reproductive adaptation; water stress

\section{Introduction}

Moringaceae is a family consisting of 13 known perennial species from a dry tropical origin [1] and certain species, such as M. oleifera and M. peregrina, can potentially be grown under arid conditions. Moringa oleifera, also known as "the miracle tree," is the most widely distributed and economically important tree species in this family. Its leaves and immature pods are highly nutritious. It is traditionally utilized as a food crop throughout the dry tropics in Asia, Africa, and America, with very little cultivation in arid regions [2]. It is also cultivated as a source of seed oil for food, bioenergy, and cosmetics [3-5]. Various plant parts are used as natural medicine [6,7], and seed powder is used as a coagulant for water purification [8]. Moringa peregrina is the second most utilized Moringa species [1]. It is a wild tree, highly tolerant to heat and drought [9], originating in the desert along the Red Sea throughout the Arabian Peninsula. M. peregrina is a highly nutritious tree grown primarily for human consumption, medicinal purposes, and animal fodder [10]. The seeds of $M$. peregrina provided oil for food and cosmetics in antiquity [11]. However, 
its commercial value as a food and medicinal and industrial commodity has rarely been explored $[12,13]$.

M. oleifera is cultivated in tropical climatic regions worldwide, while arid regions are being carefully explored for its cultivation. M. peregrina, on the other hand, is well-adapted to arid conditions with $<200-300 \mathrm{~mm}$ rainfall and is, therefore, considered to be droughttolerant. Both Moringa species require hot and dry conditions with sufficient water supply for growth and reproduction. When grown in arid regions such as the Negev and Arava Deserts in Israel, they have better performances, both vegetatively and reproductively, than when grown under wetter and colder conditions, as long as they are sufficiently irrigated and saturation of the soil with water is avoided by proper drainage [14].

In our previous study, we assessed both M. oleifera and M. peregrina as potential seed-oil and seed-protein sources under semi-arid, Mediterranean conditions [15]. We found that $M$. oleifera was better suited for oil and protein production than M. peregrina under semi-arid conditions. It produced more seeds more predictably than M. peregrina. M. peregrina, on the other hand, produced larger seeds with higher oil concentrations and was less susceptible to local diseases than M. oleifera.

The floral morphologic and chemical traits and the pollination services provided by pollen vectors of $M$. oleifera and M. peregrina are vital to their reproductive success. Both M. oleifera and M. peregrina have zygomorphic and horizontally oriented hermaphroditic flowers with five sepals, five petals, and five unequal stamens surrounding a single pistil (Figure 1) consisting of one open-type stigma and a hollow stylar tube. At maturity, the posterior petal remains erect, while the others are reflexed together with the sepals. The intermediate and front petals are curved forward, bearing short trichomes on their ventral side, and they function as a landing platform for visiting insects [16]. Flower anthesis of $M$. oleifera is associated with a temperature range of $27-29^{\circ} \mathrm{C}$ and relative humidity of $68-78 \%$. The flowers are protandrous and herkogamous. At anthesis, the anthers dehisce through longitudinal slits releasing spheroidal pollen grains $(\sim 35 \mu \mathrm{m})$ while the style remains shorter than the anthers [17]. After $\sim 24 \mathrm{~h}$, the style elongates beyond the length of the anthers, and the stigma becomes receptive for the next $48 \mathrm{~h} \mathrm{[18].} \mathrm{A} \mathrm{similar} \mathrm{floral} \mathrm{structure}$ and phenological pattern were recorded for M. peregrina by Vaknin and Mishal [15].

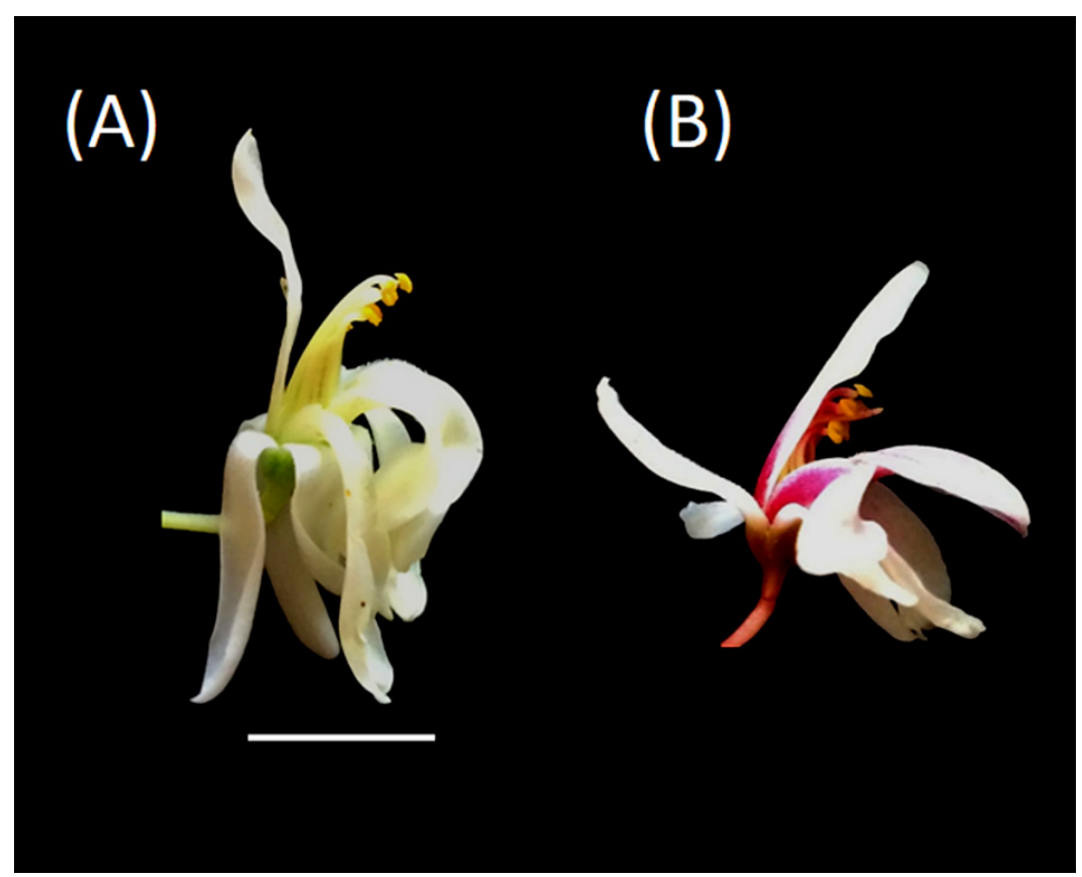

Figure 1. Open flowers of M. oleifera (A) and M. peregrina (B). Scale bar is $1 \mathrm{~cm}$.

Pollination and fertilization of M. oleifera were studied in India by Bhattacharya and Mandal [19]. They reported that floral anthesis occurred before noon, and the anthers 
opened shortly after the anthesis and produced ca. 23,000 pollen grains per flower. The average fruit set was approximately $10 \%$ and resulted from successful pollination by visiting insects, primarily carpenter bees (Xylocopa sp.). They also clarified that successful pollination requires the insertion of pollen grains into the stylar tube by the visiting insect. In Israel, M. peregrina blooms during spring and summer (March-July), and the flowers are visited by a wide range of invertebrates, mainly honeybees (Apis mellifera) and yellow carpenter bees (Xylocopa pubescence) (Vaknin, personal information). These two Moringa species produce pollen that is heavily immersed in a sticky fluid-like pollenkitt. However, comparative floral traits and pollination and fertilization biology of these species have rarely been studied before. Furthermore, the significance of the reproductive traits of the two Moringa species for their reproductive success under arid conditions has barely been tested.

Here, we attempted to elucidate the significance of the reproductive traits of $M$. oleifera and M. peregrina, associated with the interactions between pollen grains and pollen and floral style, for their reproductive success under arid conditions.

\section{Materials and Methods}

To elucidate the roles of the pollenkitt outside of the stylar tube in protecting from the hot and dry conditions associated with arid regions, we tested first whether the pollenkitt enabled pollen insertion into the stylar tube. We then tested the effects of the pollenkitt, inside and outside of the stylar tubes, on pollen viability and pollen germinability under extreme temperatures. We also tested the impact of the pollenkitt on pollen germinability under low relative humidity. To provide further insight on the functionality of the pollenkitt under arid conditions, we analyzed the chemical composition of the pollenkitts of $M$. oleifera and M. peregrina.

\subsection{In Vitro Pollen Viability and Germinability Tests}

Samples of flowers and pollen were acquired from a M. oleifera and M. peregrina plantation at Volcani Center research institute in central Israel $\left(31^{\circ} 59^{\prime} 14.25^{\prime \prime} \mathrm{N}, 34^{\circ} 49^{\prime} 27.50^{\prime \prime} \mathrm{E}\right)$. Local climatic conditions are hot and dry in summer, and cool and wet in winter, with an average annual precipitation of $524 \mathrm{~mm}$ (Israel Meteorological Service). At anthesis, 3-5 fresh Moringa flowers were randomly sampled for pollen viability and germinability tests from a Moringa plantation at the ARO campus in central Israel. Pollen viability was tested using the 3,3'diaminobenzidine (DAB) staining technique [20]. The percentage of viable pollen was calculated by observing 100 pollen grains under an Olympus Cx33 light microscope (Southend-on-Sea, UK). Pollen in vitro germinability was evaluated by incubation under a $10 \%(w / w)$ sucrose solution supplemented with $200 \mu \mathrm{g} / \mathrm{mL} \mathrm{H}_{3} \mathrm{BO}_{3}$. Pollen was inoculated into micro-wells $(n=6)$ containing $50 \mu \mathrm{L}$ of solution and incubated at $25^{\circ} \mathrm{C}$ and $40 \% \mathrm{RH}$ for $4 \mathrm{~h}$. Due to the very high number of pollen grains being clumped together, we could not count individual germinating pollen grains, and germinability was evaluated on a scale of 1 to 5 , with 1 representing very low germinability and 5 representing very high germinability (Figure 2). 


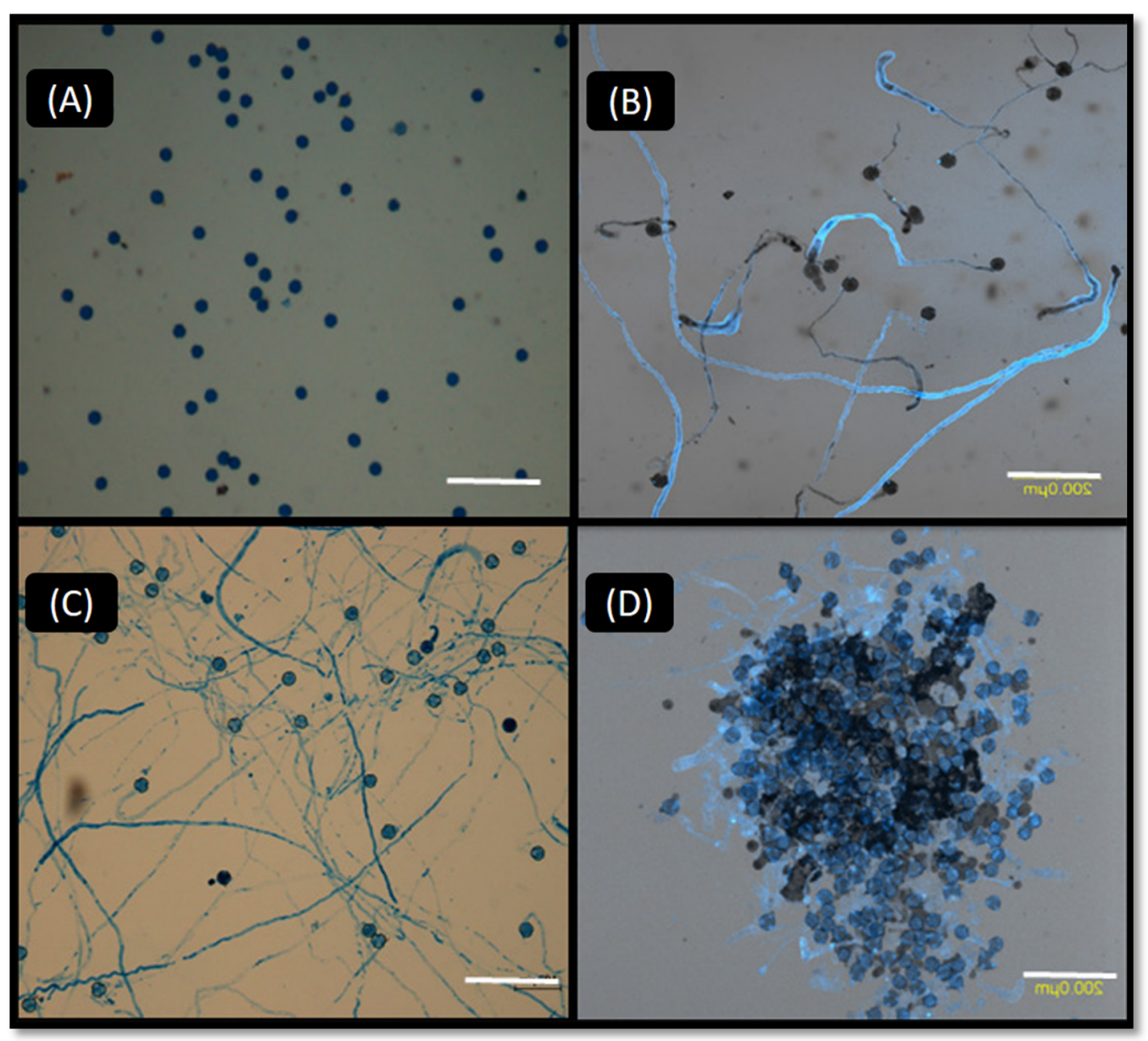

Figure 2. Various levels of in vitro pollen germinability: zero germinability (A), low germinability (B), high germinability (C), and high germinability of clumped pollen (D). The scale bar is $200 \mu \mathrm{m}$.

\subsection{Removal of the Pollenkitt}

To elucidate the significance of the pollenkitt for the pollen grains, we compared different pollen traits, with and without the pollenkitt. A method to remove the pollenkitt from the pollen grains without harming their viability [21] was followed with minor modification. The pollenkitt was removed by immersing fresh pollen grains in Eppendorf vials filled with $0.5 \mathrm{~mL}$ hexane, and the vials were vortexed for $5 \mathrm{~min}$. Then the vials were centrifuged at 10,000 RPM, the liquid was decanted, and the process was repeated as a second wash with hexane. The remaining liquid, covering the pollen grains, was fully evaporated for $1 \mathrm{~h}$. The remaining pollen grains, with their pollenkitt being removed, were then used for the tests of pollen viability, pollen germinability, and pollen insertion compared to the intact ones.

\subsection{Test of Pollenkitt for Pollen Insertion into the Stylar Tube}

First, fresh pollen grains with and without pollenkitt were spread onto a microscope slide in a thin layer. Then the tip of the style of the unpollinated fresh Moringa flowers was repeatedly brushed against the pollen grains at a $45^{\circ}$ angle until a clump of pollen grains appeared at the tip of the style. Excess pollen grains were removed from the tip of the style. The style was laid on a microscope slide, and the pollen was squeezed out from the stylar tube onto the slide with a dissecting needle. The pollen grains were stained using a single drop of Basic Fuchsin, and the numbers of them were counted under the microscope. 
2.4. Effects of Temperature on Pollen Viability and Germinability, with or without Pollenkitt, inside the Stylar Tube

To test the effects of temperature on in vitro pollen viability and germinability, fresh pollen from the anthers and those after removal of the pollenkitt from the pollen grains were placed in open Eppendorf vials and exposed to various temperatures $\left(-20^{\circ} \mathrm{C}, 4^{\circ} \mathrm{C}\right.$, $25^{\circ} \mathrm{C}$, and $40^{\circ} \mathrm{C}$ ) for $24 \mathrm{~h}$. These temperatures were arbitrarily selected to cover a broad spectrum of temperatures, from extremely low, through low and moderate, to high ambient temperatures during bloom, these temperatures being $-20{ }^{\circ} \mathrm{C}, 4{ }^{\circ} \mathrm{C}, 25^{\circ} \mathrm{C}$, and $40{ }^{\circ} \mathrm{C}$, respectively. Although not present in real life, $-20^{\circ} \mathrm{C}$ was also added to test for extreme temperatures on the lower part of the spectrum. Following exposure to different ambient temperatures, the viability and germinability of the pollen grains were tested. As a control, fresh pollen, with or without pollenkitt, was also tested for germinability at $25^{\circ} \mathrm{C}$.

Similarly, we took fresh pollen from the anthers. After removing the pollenkitt from a portion of the pollen grains, we inserted the pollen, with or without the pollenkitt, into the stylar tubes as described above. We placed the styles in open Petri dishes and exposed them to various temperatures $\left(-20^{\circ} \mathrm{C}, 4{ }^{\circ} \mathrm{C}, 25^{\circ} \mathrm{C}\right.$, and $\left.40^{\circ} \mathrm{C}\right)$ for $24 \mathrm{~h}$. Following exposure to different ambient temperatures, we squeezed out the pollen grains using a dissecting needle and tested them for viability only, due to the relatively low number of pollen grains inserted into the stylar tube.

\subsection{Test for Germinability under Low RH}

To test the effects of relative humidity on in vitro pollen germinability, fresh $M$. oleifera pollen was taken from the anthers, and a portion of it was tested for germinability. Then, the pollenkitt was removed, and they were divided into two groups; one was tested immediately for germinability and the other was placed in a closed chamber with 100\% $\mathrm{RH}$ for $1 \mathrm{~h}$ and was subsequently tested for germinability.

\subsection{Observation of Pollen on Anthers, Insects, and inside the Stylar Tube}

At anthesis, SEM imaging of pollen grains taken from newly opened anthers and gold-coated in a vacuum was carried out using a scanning electron microscope (SEM) (JEOL 840A, Tokyo, Japan). External observations of deposited pollen grains on visiting insects, i.e., honeybees (Apis mellifera) and carpenter bees (Xylocopa pubescens), were carried out using a Leica DM LB stereomicroscope. Images were acquired using a Leica DC-200 digital camera (Leica Microsystems, Wetzlar, Germany). A confocal microscopy study was carried out on the styles of open-pollinated flowers to view the pollen grains inside the stylar tube. The styles were prepared and stained using a modification of the Aniline blue epifluorescence method [22]. Stained styles were placed on a microscope slide and observed by an Olympus 1X-81 (Olympus Co., Tokyo, Japan) inverted laser scanning confocal microscope (Fluoview 500) equipped with a diode $405 \mathrm{~nm}$ laser and a $10 \times 0.4$ numerical aperture or $20 \times 0.7$ numerical aperture UPlanApo objective, at an excitation laser line of $405 \mathrm{~nm}$ and emission filter barrier of 430-460.

\subsection{Estimation of Weight Ratio of Pollenkitt to Pollen Grain}

Fresh pollen from several flowers was placed in an Eppendorf vial and weighed using a scale (Pionner ${ }^{\mathrm{TM}}$, Ohaus Corp. Parsippany, NJ, USA) to an accuracy of $0.0001 \mathrm{~g}$. The pollenkitt was removed, as described above, and the pollen grains were reweighed to estimate the percentage of the weight of the pollenkitt.

\subsection{GC-MS Chemical Analysis of the Pollenkitt}

Hexane extracts of pollen grains (see above, pollenkitt removal) or head-space samples ( $n=3$ for both), collected after exposure for $30 \mathrm{~min}$ at $60^{\circ} \mathrm{C}$, were analyzed on an Agilent GC-MSD apparatus (Agilent 6890/5977A GC-MS system, Agilent, CO, USA) equipped with an Rtx-5SIL MS ("Restek") (30 $\mathrm{m} \times 0.25 \mathrm{~mm}$ i.d., $0.25 \mu \mathrm{m}$ film thickness) fused-silica capillary column. Helium at constant pressure (13 p.s.i.) was used as a carrier gas with 
retention time locking. Samples of the extracts were injected in splitless injection modes. The injection temperature was $250^{\circ} \mathrm{C}$, and the detector temperature was $300^{\circ} \mathrm{C}$. Column conditions were $50{ }^{\circ} \mathrm{C}$ for $2 \mathrm{~min}$, followed by an increase of $15{ }^{\circ} \mathrm{C} / \mathrm{min}$ to $300{ }^{\circ} \mathrm{C}$, then kept for $15 \mathrm{~min}$ at $300^{\circ} \mathrm{C}$. For MS detection, we used an electron ionization system with ionization energy of $70 \mathrm{eV}$. MS information, covering a mass range from 50-500 atomic mass units, was collected with the full-scan mode. Molecular identification was undertaken via the NIST MS Search v2.0 software, Gaithersburg, MD, USA.

\subsection{Statistical Analyses}

Statistical analyses were performed with JMP 14.0.0 software (SAS Institute Inc. Cary, NC, USA). A two-tailed $t$-test was applied to compare pollen insertion into the stylar tube, with and without the pollenkitt, for $M$. oleifera and M. peregrina, and to compare the pollen grain to pollenkitt weight ratios of $M$. oleifera or $M$. peregrina. Comparisons of the effects of various temperatures on pollen viability, with and without pollenkitt, on the anthers and inside the stylar tube were carried out by two-way ANOVA followed by one-way ANOVA and post hoc Tukey HSD tests, for either M. oleifera or M. peregrina. Comparisons of the effects of various temperatures on pollen germinability, with or without pollenkitt, were carried out by Kruskal-Wallis tests and post hoc Dunn's tests for M. oleifera and M. peregrina. All data are represented as the mean \pm standard error. Values are reported as significantly different if $p<0.05$.

\section{Results}

\subsection{The Significance of the Pollenkitt for Pollen Insertion into the Stylar Tube}

Pollen grains of both Moringa species penetrated the stylar tube at relatively large numbers of $337 \pm 31.5$ and $252 \pm 30.5$ on average for $M$. oleifera and $M$. peregrina, respectively. When the pollenkitt was removed, less than $65 \%$ of pollen grains penetrated the stylar tube for M. oleifera $(118+15.6 ; t=6.24, p<0.0001)$ and $M$. peregrina $(88 \pm 17.6 ; t=4.66$, $p<0.0001)$. It was also observed that, without pollenkitt, pollen grains repelled each other and scattered to all directions at the entrance to the stylar tube.

\subsection{Effects of Temperatures on Pollen Viability and Pollen Germinability, with and without Pollenkitt}

Analysis of two-way ANOVA for M. oleifera revealed a significant difference in pollen viability between pollen grains exposed to different temperatures $(p<0.0001)$ and between pollen grains with and without pollenkitt $(p<0.0001)$. A significant interaction was also revealed between the temperatures and the presence and absence of pollenkitt $(p<0.0001)$. The intact pollen grains retained their relatively high viability under the temperatures tested, with the highest level of $93 \%$ at $25{ }^{\circ} \mathrm{C}$ and the significantly lowest level of $72 \%$ at $40{ }^{\circ} \mathrm{C}$ (Figure 3A; Tukey HSD $p=0.0001$ ). When the pollenkitt was removed, all levels of viability were reduced by $9-15 \%$ at $-20{ }^{\circ} \mathrm{C}, 4{ }^{\circ} \mathrm{C}$, and $25^{\circ} \mathrm{C}$ and by a drastic $79 \%$ at $40{ }^{\circ} \mathrm{C}$, from a viability of $73 \%$ to a viability of $15 \%$ (Figure $3 \mathrm{~A}$ ). Pollen germinability showed a similar trend, with a more drastic and statistically significant reduction, from nearly maximal levels, under all temperatures for intact pollen grains, to nearly $50 \%$ reduction in germinability once the pollenkitt was removed (Figure $4 \mathrm{~A}$; Kruskal-Wallis $p<0.0001$ ). The most significant reductions in germinability, by almost $60 \%$, were detected for pollen grains with their pollenkitt removed and exposed to $25^{\circ} \mathrm{C}$ and $40{ }^{\circ} \mathrm{C}$ (Dunn's tests $p<0.05$ ). 

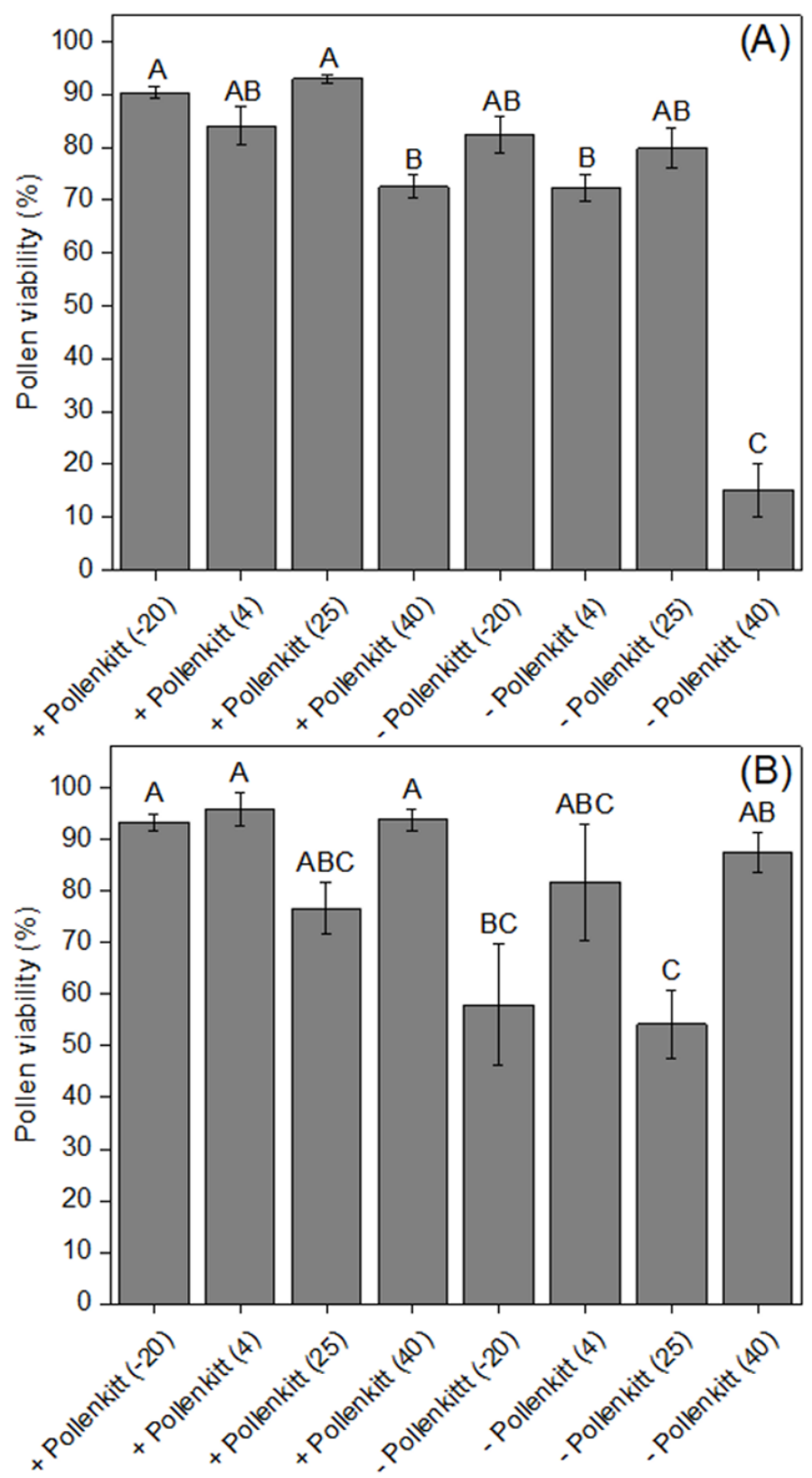

Figure 3. Effects of exposure to various temperatures (values in parentheses) on pollen viability of M. oleifera (A) and M. peregrina (B), with (+) and without $(-)$ pollenkitt. Values are means \pm SE. Different letters indicate significant differences at $p<0.05$.

Analysis of two-way ANOVA for $M$. peregrina revealed a significant difference in pollen viability between pollen grains exposed to different temperatures $(p=0.0018)$ and between pollen grains with and without the pollenkitt $(p=0.0002)$. However, no significant interaction was revealed between the temperatures and the presence and absence of pollenkitt ( $p=0.1746$ ). The intact pollen grains retained their relatively high viability under all temperatures tested, with the highest levels of $93 \%, 95 \%$, and $94 \%$ measured at $-20{ }^{\circ} \mathrm{C}$, $4{ }^{\circ} \mathrm{C}$, and $40{ }^{\circ} \mathrm{C}$, respectively, and the lowest level of $77 \%$ measured at $25^{\circ} \mathrm{C}$ (Figure 3B). When the pollenkitt was removed, all levels of viability were reduced. However, more drastic reductions were measured under the temperatures of $-20{ }^{\circ} \mathrm{C}$ and $25^{\circ} \mathrm{C}$, and much smaller reductions were measured at $4{ }^{\circ} \mathrm{C}$ and $40^{\circ} \mathrm{C}$ (Figure 3B). Pollen germinability of intact pollen grains was nearly maximal under temperatures of $-20^{\circ} \mathrm{C}$ and $4{ }^{\circ} \mathrm{C}$ and was non-significantly reduced by $27-37 \%$ at $25^{\circ} \mathrm{C}$ and $40^{\circ} \mathrm{C}$ (Figure $4 \mathrm{~A}$ ). When the pollenkitt 
was removed, the levels of germinability at $-20{ }^{\circ} \mathrm{C}$ and $4{ }^{\circ} \mathrm{C}$ were also reduced by $34-37 \%$, while at $40{ }^{\circ} \mathrm{C}$ the pollen grains completely lost their ability to germinate (Figure $4 \mathrm{~A}$; Dunn's tests $p<0.05)$.
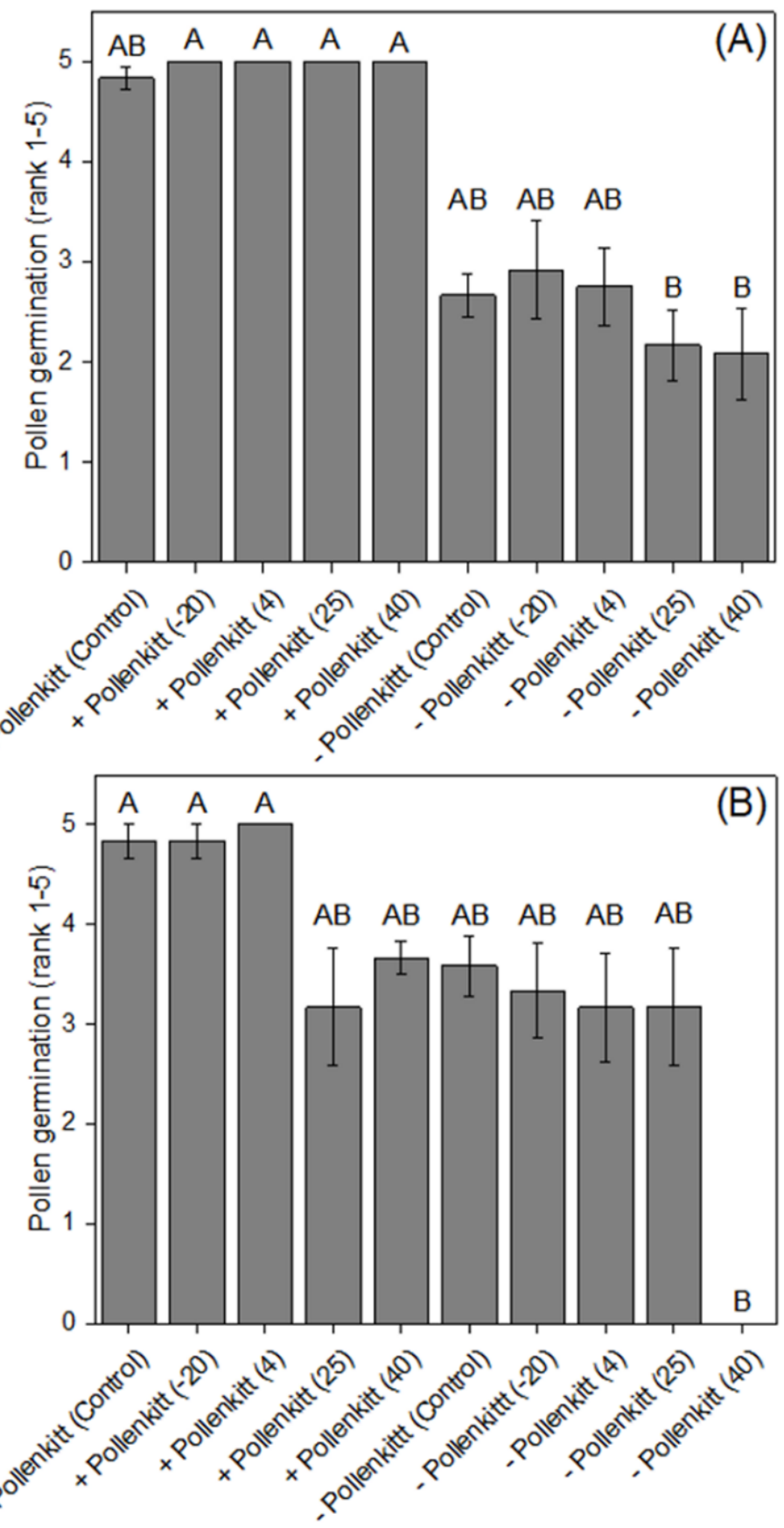

Figure 4. Effects of exposure to various temperatures (values in parentheses) on pollen germinability of M. oleifera (A) and M. peregrina (B), with (+) and without (-) pollenkitt. Values are means $\pm \mathrm{SE}$. Different letters indicate significant differences at $p<0.05$.

Thus, while $M$. oleifera pollen grains retained their viability under high temperatures and lost some of their viability when the pollenkitt was removed, the M. peregrina pollen grains retained most of their viability at $40{ }^{\circ} \mathrm{C}$. However, under this condition, they completely lost their ability to germinate. 


\subsection{Effects of Extreme Temperatures on Pollen Germinability inside the Stylar Tube}

Under extreme temperatures, both M. oleifera and M. peregrina pollen retained most of their viability within the stylar tube (Figure 5). At the temperatures of $-20^{\circ} \mathrm{C}$ and $4{ }^{\circ} \mathrm{C}$, both $M$. oleifera and $M$. peregrina intact pollen grains had $72-76 \%$ viability, while at $25^{\circ} \mathrm{C}$ and $40{ }^{\circ} \mathrm{C}$, they showed higher values of viability of $88 \%$ and $93 \%$, respectively. Without the pollenkitt, the viability of the pollen grains within the stylar tube was relatively high for both $M$. oleifera and $M$. peregrina under all measured temperatures, ranging from $86-95 \%$ for M. oleifera (Figure 5A) and $88-100 \%$ for M. peregrina (Figure 5B).
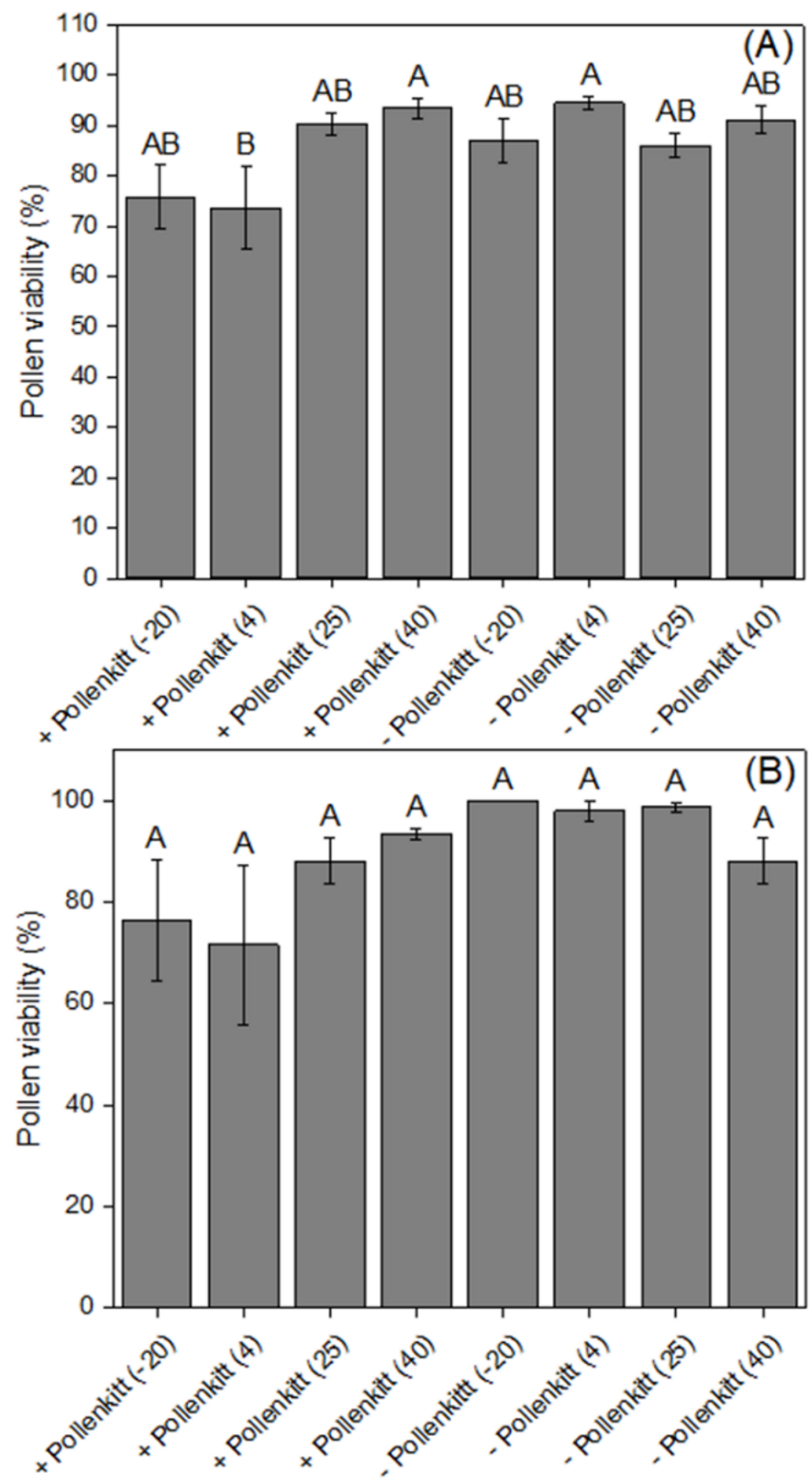

Figure 5. Effects of exposure to various temperatures (values in parentheses), inside the stylar tube, on pollen viability of $M$. oleifera $(\mathbf{A})$ or $M$. peregrina $(\mathbf{B})$, with $(+)$ or without $(-)$ pollenkitt. Values are means \pm SE. Different letters indicate significant differences at $p<0.05$. 
Two-way ANOVA for M. oleifera did not reveal significant differences in pollen viability between pollen grains inside the stylar tube and exposed to different temperatures $(p=0.0806)$. Removal of the pollenkitt, however, revealed significant effects on pollen viability inside the stylar tube $(p<0.0001)$, with a slight increase in viability for pollen grains without pollenkitt and exposed at $-20^{\circ} \mathrm{C}$ and $4{ }^{\circ} \mathrm{C}$ (Figure 5A). A significant interaction was also revealed between temperature and presence of pollenkitt $(p=0.0159)$, suggesting a different effect of temperature depending on whether the pollen grains inside the stylar tube were coated with pollenkitt or not. Analysis of two-way ANOVA for M. peregrina did not show significant differences in pollen viability between pollen grains inside the stylar tube and those exposed to different temperatures $(p=0.6873)$. Removal of the pollenkitt significantly affected pollen viability inside the stylar tube $(p<0.0001)$, showing a slight increase in viability for pollen grains exposed to $-20{ }^{\circ} \mathrm{C}, 4^{\circ} \mathrm{C}$, and $25^{\circ} \mathrm{C}$, and a slight decrease for pollen grains exposed to $40^{\circ} \mathrm{C}$ (Figure 5B).

\subsection{The Significance of the Pollenkitt for Germinability under Low RH}

We found that within several hours of pollenkitt removal from the pollen grains, their germinability was significantly reduced from the highest level of 5.0 to the lowest level of $\sim 1.0$ (Figure 6; Kruskal-Wallis $p=0.0004$, post hoc Dunn's test $p=0.0003$ ). However, after $1 \mathrm{~h}$ of exposure to high $\mathrm{RH}$, the pollen grains restored most of their germinability to level 4.0 (Figure 6).

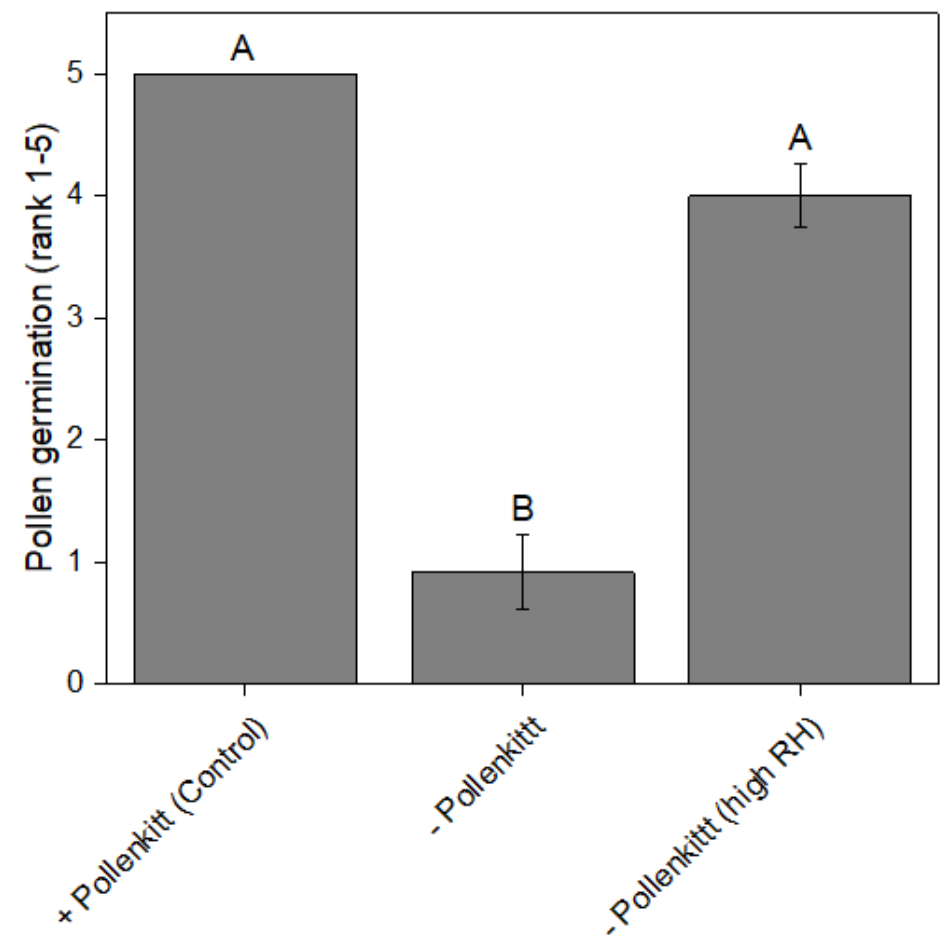

Figure 6. Effects of removal of pollenkitt $(-)$ and exposure to high relative humidity for $1 \mathrm{~h}$ on pollen germination of $M$. oleifera, with $(+)$ or without $(-)$ pollenkitt. Values are means $\pm S E$. Different letters indicate significant differences at $p<0.05$.

\subsection{Morphological Analyses on Flowers and Insects and within the Stylar Tube}

SEM analysis of $M$. oleifera pollen grains in the anthers revealed that the pollen grains were immersed in a thick grainy substance that was coating them and was also filling the space between them (Figure 7A). Thus, the pollen grains in the anthers were glued together, forming large clumps (Figure 7A). SEM analysis of a pollinated floral style showed the entrance to the stylar tube filled with pollen (Figure 7B). Confocal microscopy of the pollinated style revealed that the stylar tube was filled with pollen grains and only a few of 
them protruded beyond the tip of the style (Figure 7C). Microscopic analysis of the heads of the visiting carpenter bees revealed that their eyes and antennae were coated with sticky pollen grains and straight grooves, forming an $\mathrm{X}$ shape that appeared between the eyes and antennae of the bees (Figure 7D).
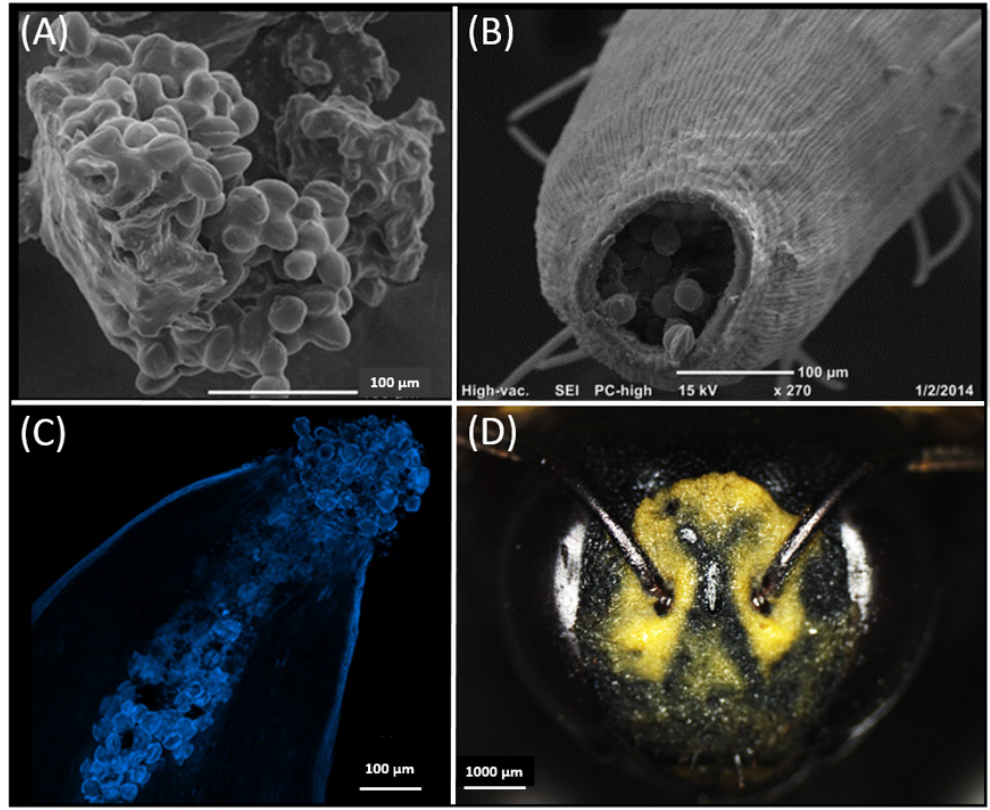

Figure 7. Morphological imaging of M. oleifera pollen grains: in a large clump coated with pollenkitt (A-SEM), at the entrance to the stylar tube (B-SEM), inside the stylar tube (C - confocal microscope), and on the head of a carpenter bee between the antennae (D-stereomicroscope).

\subsection{Estimation of Weight Ratio of the Pollenkitt to the Pollen Grains}

Weight analysis of the pollenkitt, compared to the weight of the pollen grains, revealed that the majority of the pollen, collected by the visiting insects, was the pollenkitt, constituting approximately $60 \%$ of the weight of the pollen $(58.8 \% \pm 2.4$ and $59.3 \% \pm 1.9$ for $M$. oleifera and $M$. peregrina, respectively). No significant difference was detected between the two Moringa species ( $t$-test, $p=0.437929$ ).

\subsection{GC-MS Chemical Analysis of the Pollenkitt}

Chemical analysis of the pollenkitt of both $M$. oleifera and $M$. peregrina revealed that the hexane extract was a waxy blend of 21 compounds. The blend included $11 n$-alkanes, 2 fatty acids (oleic and/or palmitic acid), 4 long-chain aldehydes, 1 sesquiterpene (transnerolidol), 1 sterol ( $\gamma$-sitosterol), and 2 tocopherols (both $\alpha$ and $\gamma$ ) (Table 1$)$. Although in tiny quantities, the pollenkitt of the two Moringa species differed primarily in the absence of long-chain aldehydes in the $M$. oleifera pollenkitt and the near absence of tocopherols in the $M$. peregrina pollenkitt. Of the 11 alkanes identified, four constituted approximately $80 \%$ of the pollenkitt extract in both species. In M. oleifera, the alkanes constituted about $94 \%$ of the extracted pollenkitt. Pentacosane ( $n$-C25), heptacosane ( $n$-C27), nonacosane (n-C29), and hentriacontane ( $n$-C 31 ) comprised about $28 \%, 20 \%, 17 \%$, and $15 \%$ of the hexane extract, respectively, amounting to $80.2 \%$ in total of the extracted pollenkitt (Table 1). In M. peregrina, the alkanes constituted approximately $92 \%$ of the extracted pollenkitt. The same alkanes, pentacosane (n-C25), heptacosane (n-C27), nonacosane (n-C29), and hentriacontane (n-C31), constituted approximately $24 \%, 24 \%, 19 \%$, and $16 \%$ of the hexane extract, respectively, amounting to $82.5 \%$ in total of the extracted pollenkitt (Table 1 ). 
Table 1. Comparative chemical analysis of the pollenkitt of M. oleifera and M. peregrina extracted by hexane.

\begin{tabular}{|c|c|c|c|c|}
\hline Chemical Name & $\begin{array}{c}\text { Molecular } \\
\text { Formula }\end{array}$ & $\begin{array}{c}\text { Retention } \\
\text { Time }\end{array}$ & M. oleifera & M. peregrina \\
\hline Trans-nerolidol & $\mathrm{C}_{15} \mathrm{H}_{26} \mathrm{O}$ & 12.321 & $1.22 \pm 0.31$ & -- \\
\hline 9-methyl-nonadecane & $\mathrm{C}_{20} \mathrm{H}_{32}$ & 14.859 &.- & $0.54 \pm 0.29$ \\
\hline Palmitic acid & $\mathrm{C}_{16} \mathrm{H}_{32} \mathrm{O}_{2}$ & 15.138 & $1.32 \pm 0.38$ & $1.51 \pm 0.75$ \\
\hline Oleic acid & $\mathrm{C}_{18} \mathrm{H}_{34} \mathrm{O}_{2}$ & 16.268 & -- & 0.42 \\
\hline Tricosane & $\mathrm{C}_{23} \mathrm{H}_{48}$ & 17.228 & $3.48 \pm 0.12$ & $5.54 \pm 16$ \\
\hline Tetracosane & $\mathrm{C}_{24} \mathrm{H}_{50}$ & 17.78 & $1.22 \pm 0.21$ & $1.8 \pm 0.18$ \\
\hline N.I, long chain & Aldehyde & 18.129 & -- & $0.65 \pm 0.15$ \\
\hline Pentacosane * & $\mathrm{C}_{25} \mathrm{H}_{52}$ & 18.327 & $23.74 \pm 0.05$ & $27.98 \pm 3.87$ \\
\hline N.I, long chain & Aldehyde & 18.432 & -- & 0.45 \\
\hline Hexacosane & $\mathrm{C}_{26} \mathrm{H}_{54}$ & 18.828 & $2.31 \pm 0.31$ & $2.27 \pm 0.13$ \\
\hline N.I, long chain & Aldehyde & 19.134 &.- & $0.58 \pm 0.18$ \\
\hline Heptacosane * & $\mathrm{C}_{27} \mathrm{H}_{56}$ & 19.392 & $24.34 \pm 0.08$ & $20.22 \pm 1.39$ \\
\hline Octacosane & $\mathrm{C}_{28} \mathrm{H}_{58}$ & 19.975 & $1.23 \pm 1.26$ & 0.68 \\
\hline N.I* long chain & Aldehyde & 20.085 & -- & $3.97 \pm 1.48$ \\
\hline Nonacosane * & $\mathrm{C}_{29} \mathrm{H}_{60}$ & 20.678 & $18.50 \pm 0.02$ & $17.08 \pm 0.61$ \\
\hline Triacontane & $\mathrm{C}_{30} \mathrm{H}_{62}$ & 21.455 & $1.33 \pm 0.88$ & $0.94 \pm 0.12$ \\
\hline$\gamma$-Tocopherol & $\mathrm{C}_{28} \mathrm{H}_{48} \mathrm{O}_{2}$ & 21.995 & $1.41 \pm 0.06$ & 0.36 \\
\hline Hentriacontane * & $\mathrm{C}_{31} \mathrm{H}_{64}$ & 22.414 & $15.95 \pm 0.1$ & $14.92 \pm 2.15$ \\
\hline$\alpha$-Tocopherol & $\mathrm{C}_{29} \mathrm{H}_{50} \mathrm{O}_{2}$ & 22.788 & $1.37 \pm 0.68$ & -- \\
\hline Tritriacontane & $\mathrm{C}_{33} \mathrm{H}_{68}$ & 24.865 & $1.91 \pm 0.13$ & -- \\
\hline$\gamma$-Sitosterol & $\mathrm{C}_{29} \mathrm{H}_{50} \mathrm{O}$ & 25.297 & $0.68 \pm 0.26$ & -- \\
\hline Total & & & $100(82.53 *)$ & $100(80.2 *)$ \\
\hline
\end{tabular}

* Four most abundant chemicals in the pollenkitt. The total amount of the four chemicals in parentheses. MFmolecular formula, R.T.- retention time.

Head-space analysis of the volatiles emitted by the pollen grains revealed that they constituted 33 compounds, including $13 n$-alkanes, 2 fatty acids (palmitic and stearic), 2 aldehydes, and a list of 16 aromatic constituents (Table 2). However, while most chemical constituents occurred in M. oleifera $(n=32)$, M. peregrina had significantly fewer volatile constituents $(n=24)$ (Table 2).

Table 2. Comparative head-space chemical analysis of the volatiles emitted by the pollen grains of M. oleifera and M. peregrina.

\begin{tabular}{|c|c|c|c|c|}
\hline Chemical Name & $\begin{array}{l}\text { Molecular } \\
\text { Formula }\end{array}$ & $\begin{array}{c}\text { Retention } \\
\text { Time }\end{array}$ & M. oleifera & M. peregrina \\
\hline Nonanal & $\mathrm{C}_{9} \mathrm{H}_{18} \mathrm{O}$ & 8.791 & $\sqrt{ }$ & $\sqrt{ }$ \\
\hline Trans-2-nonenal & $\mathrm{C}_{9} \mathrm{H}_{16} \mathrm{O}$ & 9.377 & $\sqrt{ }$ & --- \\
\hline 3'-Methylacetophenone & $\mathrm{C}_{9} \mathrm{H}_{10} \mathrm{O}$ & 9.707 & $\sqrt{ }$ & $\ldots$ \\
\hline$\alpha$-Terpineol & $\mathrm{C}_{10} \mathrm{H}_{18} \mathrm{O}$ & 9.791 & $\ldots$ & $\sqrt{ }$ \\
\hline Decanal & $\mathrm{C}_{10} \mathrm{H}_{20} \mathrm{O}$ & 9.831 & $\sqrt{ }$ & $\sqrt{ }$ \\
\hline$\alpha$-Ionol & $\mathrm{C}_{13} \mathrm{H}_{22} \mathrm{O}$ & 10.256 & $\sqrt{ }$ & $-\ldots$ \\
\hline 3-Heptylacrolein & $\mathrm{C}_{10} \mathrm{H}_{18} \mathrm{O}$ & 10.386 & $\sqrt{ }$ & $\sqrt{ }$ \\
\hline Undecanal & $\mathrm{C}_{11} \mathrm{H}_{22} \mathrm{O}$ & 10.8 & $\sqrt{ }$ & $\sqrt{ }$ \\
\hline 2,4-Decadienal & $\mathrm{C}_{10} \mathrm{H}_{16} \mathrm{O}$ & 10.928 & $\sqrt{ }$ & $\sqrt{ }$ \\
\hline 2-Undecenal & $\mathrm{C}_{11} \mathrm{H}_{20} \mathrm{O}$ & 11.324 & $\sqrt{ }$ & $\sqrt{ }$ \\
\hline Myrcene & $\mathrm{C}_{10} \mathrm{H}_{16}$ & 11.402 & $\sqrt{ }$ & -- \\
\hline Methyl cinnamate & $\mathrm{C}_{10} \mathrm{H}_{10} \mathrm{O}_{2}$ & 11.561 & $\sqrt{ }$ & $\sqrt{ }$ \\
\hline Dodecyl aldehyde & $\mathrm{C}_{12} \mathrm{H}_{24} \mathrm{O}$ & 11.71 & $\sqrt{ }$ & $\sqrt{ }$ \\
\hline$\beta$-Bisabolene & $\mathrm{C}_{15} \mathrm{H}_{24}$ & 12.987 & $\sqrt{ }$ & $\sqrt{ }$ \\
\hline Tetra decyl aldehyde & $\mathrm{C}_{14} \mathrm{H}_{28} \mathrm{O}$ & 13.379 & $\sqrt{ }$ & $\sqrt{ }$ \\
\hline 2-undecanol & $\mathrm{C}_{14} \mathrm{H}_{28} \mathrm{O}$ & 13.969 & $\sqrt{ }$ & $\sqrt{ }$ \\
\hline Pentadecanal & $\mathrm{C}_{15} \mathrm{H}_{30} \mathrm{O}$ & 14.148 & $\sqrt{ }$ & $\sqrt{ }$ \\
\hline 9-methylnonadecane & $\mathrm{C}_{20} \mathrm{H}_{42}$ & 15.691 & $\sqrt{ }$ & $\sqrt{ }$ \\
\hline
\end{tabular}


Table 2. Cont.

\begin{tabular}{|c|c|c|c|c|}
\hline Chemical Name & $\begin{array}{l}\text { Molecular } \\
\text { Formula }\end{array}$ & $\begin{array}{c}\text { Retention } \\
\text { Time }\end{array}$ & M. oleifera & M. peregrina \\
\hline Palmitic acid & $\mathrm{C}_{16} \mathrm{H}_{32} \mathrm{O}_{2}$ & 15.797 & $\sqrt{ }$ & $\sqrt{ }$ \\
\hline$\delta$-tetradecalactone & $\mathrm{C}_{14} \mathrm{H}_{26} \mathrm{O}_{2}$ & 16.99 & $\sqrt{ }$ & ---- \\
\hline Stearic acid & $\mathrm{C}_{18} \mathrm{H}_{36} \mathrm{O}_{2}$ & 17.06 & $\sqrt{ }$ & $\sqrt{ }$ \\
\hline Bisphenol A & $\mathrm{C}_{15} \mathrm{H}_{16} \mathrm{O}_{2}$ & 17.239 & $\sqrt{ }$ & $\sqrt{ }$ \\
\hline Tricosane & $\mathrm{C}_{23} \mathrm{H}_{48}$ & 18.028 & $\sqrt{ }$ & $\sqrt{ }$ \\
\hline$\delta$-Stearolactone & $\mathrm{C}_{18} \mathrm{H}_{34} \mathrm{O}_{2}$ & 18.223 & $\sqrt{ }$ & ---- \\
\hline Tetracosane & $\mathrm{C}_{24} \mathrm{H}_{50}$ & 18.441 & $\sqrt{ }$ & $\sqrt{ }$ \\
\hline Pentacosane & $\mathrm{C}_{25} \mathrm{H}_{52}$ & 18.971 & $\sqrt{ }$ & $\sqrt{ }$ \\
\hline Hexacosane & $\mathrm{C}_{26} \mathrm{H}_{54}$ & 19.485 & $\sqrt{ }$ & $\sqrt{ }$ \\
\hline Heptacosane & $\mathrm{C}_{27} \mathrm{H}_{56}$ & 20.029 & $\sqrt{ }$ & $\sqrt{ }$ \\
\hline Octacosane & $\mathrm{C}_{28} \mathrm{H}_{58}$ & 20.63 & $\sqrt{ }$ & $\sqrt{ }$ \\
\hline Nonacosane & $\mathrm{C}_{29} \mathrm{H}_{60}$ & 21.312 & $\sqrt{ }$ & $\sqrt{ }$ \\
\hline Triacontane & $\mathrm{C}_{30} \mathrm{H}_{62}$ & 22.106 & $\sqrt{ }$ & ---- \\
\hline Hentriacontane & $\mathrm{C}_{31} \mathrm{H}_{64}$ & 23.04 & $\sqrt{ }$ & ---- \\
\hline Dotriacontane & $\mathrm{C}_{32} \mathrm{H}_{66}$ & 24.156 & $\sqrt{ }$ & ---- \\
\hline
\end{tabular}

$(\sqrt{ })$ chemical present, (----) chemical not present.

\section{Discussion}

Drylands cover about $50 \%$ of the global land area and provide sustenance and livelihood for about $20 \%$ of the world's population. In these lands, precipitation provides plants with less than $65 \%$ of the potential evaporation and transpiration $\left(\mathrm{ET}_{\mathrm{p}}<0.65\right)$ [23]. The most prevailing conditions in drylands are high levels of temperature and solar irradiation and low levels of relative humidity and water availability, which pose a severe threat to the successful growth and reproduction of many staple crops [24]. Here, we attempted to elucidate adaptations in the sexual reproduction of M. oleifera and M. peregrina that allow them to grow successfully and produce leaves, seeds, and oil under these conditions.

Our emphasis on the Moringa pollenkitt was due to its uniquely high relative content of pollenkitt in both Moringa species. Pollenkitt is an adhesive material present around pollen grains of animal pollinated angiosperms. Pacini and Hesse [25] reported more than 20 functional stages, namely in the anthers, from pollen presentation in the anthers, in relation to pollinators, during pollen dispersal, and when the pollen reaches the stigma. Among those functions, some may play significant roles in protecting pollen grains against adverse conditions in arid regions, including protection from water loss, protection from UV radiation, and facilitation of pollen rehydration [25]. However, other potential functions, such as the ones tested here, including protection against high temperatures and improving the penetration of the pollen grains into the stylar tube, were not considered.

\subsection{Weight Ratio of Pollenkitt to the Pollen Grains}

The amount of pollenkitt produced by the flower depends on its pollination mechanism and the specific function of the pollenkitt in the pollination process [26]. In zoophilous species, for example, the pollenkitt provides adhesion to animal bodies for dispersal as well as to the stigmatic surface and may contain volatiles that are attractive to pollinators. In contrast, the pollenkitt in anemophilous species has a minimal function in pollen dispersal and advertisement and is almost absent in some cases [27]. However, since pollen dispersal in clumps may lead to high pollination efficiency in angiosperms, pollenkitt may be found in many types of pollination mechanisms but in different amounts [26]. Haisheng et al. [28] studied the content of pollenkitt in some wind- and insect-pollinated species and reported a range from $8 \%$ in olive pollen up to $60 \%$ in dandelion pollen. They showed that pollen adhesion was directly and positively affected by pollenkitt content. Our data fall within the upper range of this pollenkitt content. Thus, additional functions other than enhanced adhesion of pollenkitt might be considered in Moringa species. 


\subsection{The Significance of the Pollenkitt for Pollen Insertion into the Stylar Tube}

Our results suggested that the significance of the pollenkitt for pollen insertion into the stylar tube was at least threefold. First, as the insects visited the newly opened flowers, the pollen grains were evenly spread on their heads, between their antennae, in a thin and very sticky layer, thus preparing the pollen to be shuffled into the stylar tube. Then, once a large insect visited a non-pollinated flower, the open style was brushed against the thin layer of pollen and scooped up the pollen grains into the hollow tube. Second, the pollenkitt provided lubrication to allow many pollen grains to penetrate the tube and reach the receptive inner tissue. Third, since the outermost exine layer of pollen grains is electrically charged, it may cause mutual repulsion [29]. The insulating properties of the thick layer of pollenkitt probably reduced the electrostatic charges on the pollen grains. Thus, very few pollen grains repulsed each other as they penetrated the stylar tube. Due to their electrical insulating properties, natural plant waxes have been used by the industry for insulating coatings for the past 70 years or more [30]. Furthermore, the relatively large flowers of M. oleifera and M. peregrina, and the need to insert pollen grains into a narrow stylar tube, require the pollinating services of large and powerful insects. The most frequent visitor of Moringa flowers, the carpenter bee (Xylocpa sp.), is probably a perfect match to these requirements. As it pushes itself into the flower to gather nectar, sticky pollen smears on its head and, when it visits an un-pollinated flower, the open style is brushed against the pollen and gets inserted into the style. Similarly, in Cassia fistula Linn., this process also requires large and heavy-bodied insects such as carpenter bees and honey bees. Out of 650,000 pollen grains produced per flower, only $250-350$ are eventually pushed into the style [31].

\subsection{The Significance of the Pollenkitt for Protection against Heat and Water Stress}

Although they originated from two completely different regions of the world, the pollen grains of the two Moringa species studied showed relatively similar responses to extreme temperatures, prevalent under arid conditions. When exposed to high temperatures, slight reductions in pollen viability and germinability were found compared to those at room temperature, probably due to the desiccation of the pollen grains. The significance of the pollenkitt was revealed when the pollen grains were exposed to high temperatures, with and without the pollenkitt. Removal of the pollenkitt from $M$. oleifera pollen resulted in almost a complete loss of pollen viability under high temperatures and drastic reductions in germinability under all temperatures, probably due to desiccation. The statistically significant interaction between extreme temperatures and pollenkitt suggests a different effect of temperature depending on whether the pollen grains are coated with pollenkitt or not. Furthermore, exposure to high RH restored most of the germinability of the pollen grains, which supports our assertion that the pollenkitt plays a pivotal role in protecting the pollen grains against desiccation. Removal of the pollenkitt from $M$. peregrina pollen, however, resulted in a significantly smaller reduction of pollen viability under high temperatures, suggesting a better adaptation to high temperatures. Pollen germinability, however, was less reduced at cold to moderate temperatures of $-20^{\circ} \mathrm{C}$ to $25^{\circ} \mathrm{C}$, but was completely lost at high temperatures, suggesting that the viable pollen of $M$. peregrina require the pollenkitt to retain their germinability. However, germinability on the stigma occurs inside the stylar tube with conditions that are probably less desiccating than in our experiments. Thus, we have to assume that the detrimental effects of exposure to high temperatures were primarily on over-heating and desiccation of the pollen grains. The presence of the waxy pollenkitt provided some protection against these stressful conditions. Our results are supported by the work of Pacini and Hesse [25], who reported that the function of pollenkitt in protection against water loss is often weak. In most cases, it does not provide complete protection but only slows down the desiccating process.

Chemical analysis of the pollenkitt revealed a lipidic, waxy blend of hydrocarbons, primarily $n$-alkanes $(>90 \%)$, with some fatty acids, aldehydes, and aromatic volatiles. The differences between the two Moringa species were relatively small, suggesting a similar 
role for the pollenkitt for both species. The fact that the M. oleifera pollenkitt constituted more volatile components may have significance related to the attractiveness of the flowers to pollinating insects and should be further explored in future research. Hydrocarbons are known to play a critical role in protection against arid conditions in both the plant and animal kingdoms. In terrestrial plants, their aerial parts, and especially the leaves, are covered by a hydrophobic cuticular layer that serves as a waterproof barrier, protecting the plants against desiccation. This layer consists of a cutin matrix as well as cuticular waxes in which very long-chain alkanes are the major components, representing up to $70 \%$ of the total wax content in the leaves. The biosynthesis of these alkanes was found to be highly linked to responses to stresses, both biotic and abiotic [32]. Leaf waxes have also been associated with protection against heat stress and cooler canopies under water limiting conditions [33,34]. In further support of this claim, Mondal et al. [35] suggested that, in wheat, production of leaf cuticular wax may contribute to lower leaf temperatures under heat stress. The epicuticular hydrocarbons of scorpions also play an important role in protecting them against desiccation and water loss under hot and arid conditions [36]. Those hydrocarbons act as an efficient barrier that limits transpiration. The most abundant $n$-alkanes were $n$-heptacosane $\left(C_{27} ; 19 \pm 2 \%\right.$ of total HCs), $n$-nonacosane $\left(C_{29} ; 16 \pm 1 \%\right)$, and $n$-hentriacontane $\left(\mathrm{C}_{31} ; 11 \pm 1 \%\right)$ [36]. Interestingly, these three $n$-alkanes are also three of the four most abundant $n$-alkanes in the Moringa pollenkitt and their relative abundance corresponds almost identically to their abundance in the pollenkitt. This type of desiccation resistance has been determined as an adaptive life-history trait dependent upon the presence of hydrocarbons known to conserve internal water stores by preventing the loss of water due to transpiration [37].

\subsection{The Significance of the Stylar Tube for Protection against Heat and Water Stress}

Our results revealed that the stylar tube of both $M$. oleifera and M. peregrina flowers protected the pollen grains against the stressful conditions imposed by the extreme temperatures, both high and low. Once inserted into the stylar tube, the pollen grains retained their relatively high levels of viability even when the pollenkitt was removed. Thus, the stylar tube provided maximal protection against heat and water stresses and offered optimal conditions for pollen germination on the inner stigmatic tissue. Only very few similar germinating conditions have been reported in the plant kingdom, as in Cyclamen persicum (Mill.) flowers, where it has been reported that Cyclamen pollen grains must also enter a hollow style to germinate [38]. The authors suggested no functional advantage, but since Cyclamen flowers bloom in the Mediterranean winter and the styles point downwards, we can assume that the hollow style provides the germinating pollen grains with some protection against the falling rain.

\section{Conclusions}

Our study attempted to elucidate the significance of floral and pollen traits of two Moringa species, one originating from the wet tropics (M. oleifera) and the other from the dry tropics (M. peregrina), for their reproductive success under arid conditions. Our results provide evidence that the pollenkitt coating the pollen grains is unique in quantity and quality. Making up the majority of the pollen weight, the pollenkitt protects against extreme temperatures and desiccation for both species. The unusual hollow style, with its narrow stylar tube, requires the pollination services of large and powerful insects and provides the pollen grains with protection against stressful arid conditions. Additional functionality for the pollenkitt was discovered in providing lubrication for the pollen grains in their passage into the stylar tube and in reducing undesirable electrostatic repulsion. We conclude that the reproductive success of $M$. oleifera and M. peregrina under arid conditions is enhanced mainly by their unique floral and pollen traits.

Author Contributions: Y.V., A.M., and D.E. conceived the project. Y.V., A.M., and D.E. collected data and conducted the analyses. Y.V. and A.M. wrote the manuscript. All authors have read and agreed to the published version of the manuscript. 
Funding: This research was partially supported by the Fuel Choices Initiative at the Israeli Prime Minister's office.

Institutional Review Board Statement: Not applicable.

Informed Consent Statement: Not applicable.

Data Availability Statement: Data will be provided by the authors upon request.

Acknowledgments: The authors wish to thank Hanita Zemach and Eduard Belausov in their assistance with the SEM and confocal microscopes and Hiba Haj-Yehya for her assistance in the lab and fieldworks.

Conflicts of Interest: The authors declare no conflict of interest.

\section{References}

1. Olson, M.E.; Carlquist, S. Stem and root anatomical correlations with life form diversity, ecology, and systematics in Moringa (Moringaceae). Bot. J. Linn. Soc. 2001, 135, 315-348. [CrossRef]

2. Ramachandran, C.; Peter, K.V.; Gopalakrishnan, P.K. Drumstick (Moringa oleifera): A multipurpose Indian vegetable. Econ. Bot. 1980, 34, 276-283. [CrossRef]

3. Sengupta, A.; Gupta, M.P. Studies on the seed fat composition of Moringaceae family. Fett. Wiss. Technol. 1970, 72, 6-10. [CrossRef]

4. Kleiman, R.; Ashley, D.A.; Brown, J.H. Comparison of two seed oils used in cosmetics, Moringa and Marula. Ind. Crop. Prod. 2008, 28, 361-364. [CrossRef]

5. Rashid, U.; Anwar, F.; Moser, B.R.; Knothe, G. Moringa oleifera oil: A possible source of biodiesel. Bioresour. Technol. 2008, 99, 8175-8179. [CrossRef]

6. Caceres, A.; Cabrera, O.; Morales, O.; Mollinedo, P.; Mendia, P. Pharmacological properties of Moringa oleifera. 1: Preliminary screening for antimicrobial activity. J. Ethnopharmacol. 1991, 33, 213-216. [CrossRef]

7. Holst, S. Moringa: Nature's Medicine Cabinet; Sierra Sunrise Books: Sherman Oaks, CA, USA, 2000; Volume 14622.

8. Jahn, S.A.A.; Mussad, H.A.; Burgstaller, H. The tree that purifies water: Cultivating multipurpose Moringaceae in the Sudan. Unasylva 1986, 152, 23-28.

9. Hegazy, A.K.; Hammouda, O.; Lovett-Doust, J.; Gomaa, N.H. Population dynamics of Moringa peregrina along altitudinal gradient in the northwestern sector of the Red Sea. J. Arid Environ. 2008, 72, 1537-1551. [CrossRef]

10. Alaklabi, A. Genetic diversity of Moringa peregrina species in Saudi Arabia with ITS sequences. Saudi J. Biol. Sci. 2015, 22, 186-190. [CrossRef]

11. Wilkinson, A. The Garden in Ancient Egypt; Rubicon Press: London, UK, 1998.

12. Somali, M.A.; Bajneid, A.; Fhainian, S.S. Chemical composition and characteristic of Moringa peregrina seeds and seed oil. J. Am. Oil Chem. Soc. 1984, 16, 85-86. [CrossRef]

13. Mridha, M.A.U. Prospects of Moringa cultivation in Saudi Arabia. J. Appl. Environ. Biol. Sci. 2015, 5, $39-46$.

14. Abud-Archila, M.; Espinosa-Arrioja, A.K.; González-Soto, T.; Gutiérrez-Oliva, V.F.; Ruíz-Valdiviezo, V.; González-Mendoza, D.; Rodríguez-Hernández, L.; Gutiérrez-Miceli, F.A. Growth and biochemical responses of Moringa (Moringa oleifera L.) to vermicompost and phosphate rock under water stress conditions. Phyton 2018, 87, 209-215.

15. Vaknin, Y.; Mishal, A. The potential of the tropical "miracle tree" Moringa oleifera and its desert relative Moringa peregrina as edible seed-oil and protein crops under Mediterranean conditions. Sci. Hort. 2017, 225, 431-437. [CrossRef]

16. Decraene, L.R.; De Laet, J.; Smets, E.F. Floral development and anatomy of Moringa oleifera (Moringaceae): What is the evidence for a capparalean or sapindalean affinity? Ann. Bot. 1998, 82, 273-284. [CrossRef]

17. Jyothi, P.V.; Atluri, J.B.; Reddi, C.S. Pollination ecology of Moringa oleifera (Moringaceae). Proc. Plant Sci. 1990, $100,33-42$.

18. Krieg, J.; Goetze, D.; Porembski, S.; Arnold, P.; Linsenmair, K.E.; Stein, K. Floral and reproductive biology of Moringa oleifera (Moringaceae) in Burkina Faso, West Africa. Acta Hortic. 2017, 1158, 63-69. [CrossRef]

19. Bhattacharya, A.; Mandal, S. Pollination, pollen germination and stigma receptivity in Moringa oleifera Lamk. Grana 2004, 43, 48-56. [CrossRef]

20. Dafni, A.; Neppi, M.; Pacini, E. Pollen and stigma biology. In Practical Pollination Biology; Dafni, A., Kevan, P.G., Husband, B., Eds.; Enviroquest: Cambridge, ON, Canada, 2005; pp. 83-147.

21. Evans, D.E.; Taylor, P.E.; Singh, M.B.; Knox, R.B. Quantitative analysis of lipids and protein from the pollen of Brassica napus L. Plant Sci. 1991, 73, 117-126. [CrossRef]

22. Martin, F.W. Staining and observing pollen tubes in the style by means of fluorescence. Stain Technol. 1959, 34, 125-128. [CrossRef] [PubMed]

23. Middleton, N.; Thomas, D. (Eds.) World Atlas of Desertification, 2nd ed.; Hodder Headline Group: London, UK, 1997.

24. Beaumont, P. Drylands: Environmental Management and Development; Routledge: London, UK; New York, NY, USA, 2014.

25. Pacini, E.; Hesse, M. Pollenkitt-Its composition, forms and functions. Flora-Morphol. Distrib. Funct. Ecol. Plants 2005, 200, 399-415. [CrossRef] 
26. Pacini, E.; Franchi, G.G. Some cytological, ecological and evolutionary aspects of pollination. Acta Soc. Bot. Pol. 1996, 65, 11-16. [CrossRef]

27. Heslop-Harrison, J. An interpretation of the hydrodynamics of pollen. Am. J. Bot. 1979, 1, 737-743. [CrossRef]

28. Haisheng, L.; Gomez, I.; Meredith, J.C. Pollenkitt wetting mechanism enables species-specific tunable pollen adhesion. Langmuir 2013, 29, 3012-3023.

29. Galati, B.G.; Rosenfeld, S. The pollen development in Ceiba insignis (Kunth) Gibbs \& Semir ex Chorisia speciosa St. Hil. (Bombacaceae). Phytomorphology 1998, 48, 121-130.

30. Hodge, W.H.; Sineath, H.H. The Mexican candelilla plant and its wax. Econ. Bot. 1956, 10, 134-154. [CrossRef]

31. Saradhi, P.P.; Ram, H.M. Some Aspects of floral biology of Cassia fistula Linn. (The Indian laburnum)—Part I. Curr. Sci. 1981, 50, 802-805.

32. Bourdenx, B.; Bernard, A.; Domergue, F.; Pascal, S.; Léger, A.; Roby, D.; Pervent, M.; Vile, D.; Haslam, R.P.; Napier, J.A.; et al. Overexpression of Arabidopsis ECERIFERUM1 promotes wax very-long-chain alkane biosynthesis and influences plant response to biotic and abiotic stresses. Plant Physiol. 2011, 156, 29-45. [CrossRef]

33. Richards, R.A.; Rawson, H.M.; Johnson, D.A. Glaucousness in wheat: Its development and effect on water-Use efficiency, gas exchange and photosynthetic tissue temperatures. Aust. J. Plant Physiol. 1986, 13, 465-473. [CrossRef]

34. Bennett, D.; Izanloo, A.; Edwards, J.; Kuchel, H.; Chalmers, K.; Tester, M.; Reynolds, M.P.; Schnurbusch, T.; Langridge, P. Identification of novel quantitative trait loci for days to ear emergence and flag leaf glaucousness in bread wheat (Triticum aestivum L.) population adapted to southern Australian conditions. Theor. Appl. Genet. 2012, 124, 697-711. [CrossRef] [PubMed]

35. Mondal, S.; Mason, R.E.; Huggins, T.; Hays, D.B. QTL on wheat (Triticum aestivum L.) chromosomes 1B, 3D and 5A are associated with constitutive production of leaf cuticular wax and may contribute to lower leaf temperatures under heat stress. Euphytica 2015, 201, 123-130. [CrossRef]

36. Gefen, E.; Talal, S.; Brendzel, O.; Dror, A.; Fishman, A. Variation in quantity and composition of cuticular hydrocarbons in the scorpion Buthus occitanus (Buthidae) in response to acute exposure to desiccation stress. Comp. Biochem. Phys. A 2015, 182, 58-63. [CrossRef] [PubMed]

37. Krupp, J.J.; Nayal, K.; Wong, A.; Millar, J.G.; Levine, J.D. Desiccation resistance is an adaptive life-history trait dependent upon cuticular hydrocarbons, and influenced by mating status and temperature in D. melanogaster. J. Insect Physiol. 2020, 121, 103990. [CrossRef] [PubMed]

38. Reinhardt, S.; Ewalda, A.; Hellwig, F. The Anatomy of the stigma and style from Cyclamen persicum (Mill.) cv. "pure white" and its relation to pollination success. Plant Biol. 2007, 9, 158-162. [CrossRef] [PubMed] 